Recherches en didactique des langues et des cultures

Les cahiers de l'Acedle

18-1 | 2021

En quoi les langues ont-elles un rôle à jouer dans les sociétés mondialisées au sein d'une Europe fragilisée ?

\title{
Conceptions de la langue et du plurilinguisme
}

Acedle, Asdifle et TRANSIT-Lingua

\section{(2) OpenEdition}

\section{Journals}

Édition électronique

URL : https://journals.openedition.org/rdlc/8879

DOI : $10.4000 /$ rdlc. 8879

ISSN : 1958-5772

Éditeur

ACEDLE

Référence électronique

Acedle, Asdifle et TRANSIT-Lingua, "Conceptions de la langue et du plurilinguisme ", Recherches en didactique des langues et des cultures [En ligne], 18-1 | 2021, mis en ligne le 10 juin 2021, consulté le 03 août 2021. URL : http://journals.openedition.org/rdlc/8879 ; DOI : https://doi.org/10.4000/rdlc.8879

Ce document a été généré automatiquement le 3 août 2021

\section{cc) (†) $\odot$}

Recherches en didactique des langues et des cultures is licensed under a Creative Commons AttributionNonCommercial-NoDerivatives 4.0 International License 


\title{
Conceptions de la langue et du plurilinguisme
}

\author{
Acedle, Asdifle et TRANSIT-Lingua
}

1 [A venir dans le courant de l'automne 2021]

2 Cette capsule synthétise les moments du débat participatif concernant les conceptions de la langue et du plurilinguisme. Les langues : instruments de pouvoir et de domination? Outils de communication? Expériences et manières d'être au monde?

Ce média ne peut être affiché ici. Veuillez vous reporter à l'édition en ligne http:// journals.openedition.org/rdlc/8879

\section{Chapitrage de la capsule}

\section{AUTEURS}

\section{ACEDLE}

https://acedle.org/

ASDIFLE

https://asdifle.com/

TRANSIT-LINGUA

https://transitlingua.org/ 